Article available at nttp://www.parasite-journal.org or nttp://dx.dol.org/10.1051/parasite/199603438

\title{
IMPROVEMENT OF BLOOD AND FLY GUT PROCESSING FOR PCR DIAGNOSIS OF TRYPANOSOMOSIS
}

\author{
PENCHENIER L.*, DUMAS V.**, GREBAUT P.*, REIFENBERG J.M.*** \& CUNY G.****
}

\section{Summary :}

We have adapted a simple and efficient technique to detect trypanosomes in human blood, without DNA purification, and increased the sensitivity threshold to 1 parasite in $1 \mathrm{ml}$. We have then applied it for detection of parasites in midguts of tsetse flies, negative by microscopy. This technique has been developed for field conditions and could greatly facilitate epidemiological studies.

KEY WORDS : PCR, diagnosis, Trypanosoma.
Résumé : AMÉlIORATION DU TRATTEMENT DU SANG ET DES INTESTINS DE MOUCHE POUR LE DIAGNOSTIC DE LA TRYPANOSOMOSE par PCR Nous avons adapté une technique simple et efficace pour la détection par PCR des trypanosomes dans le sang humain, sans purification d'ADN, et augmenté le seuil de sensibilité à un parasite par $\mathrm{ml}$. Nous l'avons ensuite appliquée à la détection de parasites dans des intestins de glossines infectées, négatives à l'observation microscopique. Cette technique a été développée pour une utilisation dans des conditions de terrain et pourrait faciliter les études épidémiologiques.

MOTS CLÉS : PCR, diagnostic, Trypanosoma.

\section{INTRODUCTION}

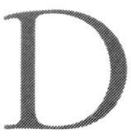
iagnosis of Trypanosoma sp. in blood is difficult, either because of low parasitemias or due to the limits of parasitological techniques: centrifugation on mini-anion exchange columns (mAEC) needs fresh blood (Lanham and Godfrey, 1970), is delicate to perform and is almost forsaken for mass detection; haematocrit centrifugation technique (HTC) is much easier to achieve (Woo, 1971), but lacks in sensitivity (detection of one parasite for $75 \mu \mathrm{l}$ of blood theoritically). PCR technology can bring the required sensitivity and specificity, but direct amplification from blood samples is very often difficult, because of haemoglobin derivatives which cause inhibition of the reaction. To overcome these problems and to increase the sensitivity treeshold, we have adapted a simple and efficient method to detect one parasite in $1 \mathrm{ml}$ of blood, without DNA purification, and tested it on samples stored in field conditions.

In tsetse flies, detection of a single parasite by PCR amplification has been achieved in proboscides and in salivary glands, but failed for midguts without DNA

\footnotetext{
* Laboratoire de recherche sur les trypanosomes OCEAC, BP 288, Yaoundé, Cameroun.

** Laboratoire d'Épidémiologie des Maladies à Vecteurs, ORSTOM, *** Laboratoire de pathologie tropicale, CIRAD/EMVT and **** Laboratoire des Rétrovirus, ORSTOM, 911 Avenue Agropolis, BP 5045, 34032 Montpellier Cedex 1, France.

Correspondance : G. Cuny. Tél. : 0467617598 - Fax : 0467547800

- e-mail: cuny@orstom.rio.net.
}

purification (Gibson et al., 1988; Masiga et al., 1992). We have then applied the same procedure to amplify trypanosomes in midguts of experimentally infected flies.

\section{MATERIALS AND METHODS}

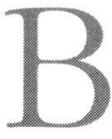
lood was taken from an healthy volunteer, on dry or EDTA tubes, aliquoted by one $\mathrm{ml}$ fractions, and one to five parasites (Trypanosoma brucei gambiense, ITMAP 1841) were added by serial dilutions or by using a micromanipulator apparatus (Leica, Wetzlar, Germany).

Samples were treated with the Ready AMP ${ }^{\mathrm{TM}}$ genomic purification kit (Promega, Madison, WI, USA) with slight modifications: briefly, $1 \mathrm{ml}$ of sterilized-nuclease free water were added to each sample, and tubes were incubated at room temperature for 10 minutes, with vortex shaking every 1-2 minutes; after centrifugation (two minutes at $13,000 \mathrm{~g}$ ) in a microcentrifuge, supernatants were discarded and $100 \mu \mathrm{l}$ of resin added. Pellets were resuspended and incubated for 20 minutes at $56{ }^{\circ} \mathrm{C}$, vortexed vigorously and put at $100{ }^{\circ} \mathrm{C}$ for 10 minutes. After 2 minutes of centrifugation at $13,000 \mathrm{~g}$, supernatants containing single sranded DNA were stored at $4{ }^{\circ} \mathrm{C}$ or used directly.

Glossina morsitans morsitans from CIRAD/ORSTOM insectarium was used in the experimental infection: five teneral flies were fed on a mouse infected with Trypanosoma congolense (savannah type, Satiri/87/CRTA/235) 
or six on a healthy rabbit, as a control for experiment. Seven days after flies were dissected. From each fly, the midgut was carefully removed and examined under the microscope. The dissecting instruments were cleaned by immersion in bleach and briefly rinsed in water, before dissection of a new fly, to avoid contamination. Each midgut was then put in $50 \mu$ of physiological serum, $100 \mu \mathrm{l}$ of resin were added and each sample was processed as above.

PCR reactions were carried out in $50 \mu \mathrm{l}$ final volume containing 1x Cetus reaction buffer, 20 pmoles of each primer, $200 \mu \mathrm{M}$ of dNTPs, $10 \mu \mathrm{l}$ of sample and one unit of Ampli Taq DNA polymerase (Perkin-Elmer, Norwalk, CT, USA). Amplification conditions were: 40 cycles with denaturation step at $94^{\circ} \mathrm{C}$ for $30 \mathrm{~s}$., annealing step at $60{ }^{\circ} \mathrm{C}$ ( T. brucei) or $67^{\circ} \mathrm{C}($ T. congolense) for $30 \mathrm{~s}$, and polymerisation step at $72{ }^{\circ} \mathrm{C}$ for one minute, on a Techne PHC-3 (Techne, Cambridge, UK). After a final elongation at $72{ }^{\circ} \mathrm{C}$ for 5 minutes, $10 \mu \mathrm{l}$ of reactions were run in $1.5 \%$ agarose gel containing $0.5 \mathrm{mg} / \mathrm{ml}$ of ethidium bromide and photographed under UV light.

Primers for amplification of T. brucei and T. congolense savannah are those described by Masiga et al., 1992.

\section{RESULTS}

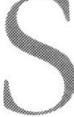

ince the aim of our studies was to perform this technique for field diagnosis, we decided to test the lower limit of detection in $1 \mathrm{ml}$ blood and storage conditions of the blood for efficient detection: blood taking was done on EDTA or dry tubes, trypanosomes added by micromanipulation and samples were kept at $4{ }^{\circ} \mathrm{C}$ for one week. Those stored in EDTA tubes were then processed directly. For the others, clots were first disrupted mechanically (by pipetting in and out) before treatment. As shown in figure 1, specific amplification (as evidenced by control experiments, lanes 3 and 6) of $164 \mathrm{bp}$ repeated monomer fragments occurred whatever the storage conditions. For dry tubes, however, bands are less intense and particularly oligomer fragments (lanes 4 and 5) probably due to loss of material in the clots, which cannot be completely disrupted. From the five teneral flies fed on a mouse infected with T. congolense savannab, only two flies appeared to be parasited at high rate, by microscopic observation, the three others being negative. All midguts were treated as described in Materials and Methods section and subjected to PCR amplification. Results are presented in figure 2. As expected, the 316 bp repeated bands (specific of T. congolense savannah) are amplified in the positive flies (lanes 1 and 2) as well as from the midgut of a non infected fly where about 100 trypanosomes were added (lane 3). Interestingly, from the three negatives by microscopy, one shows amplification of T. congo-

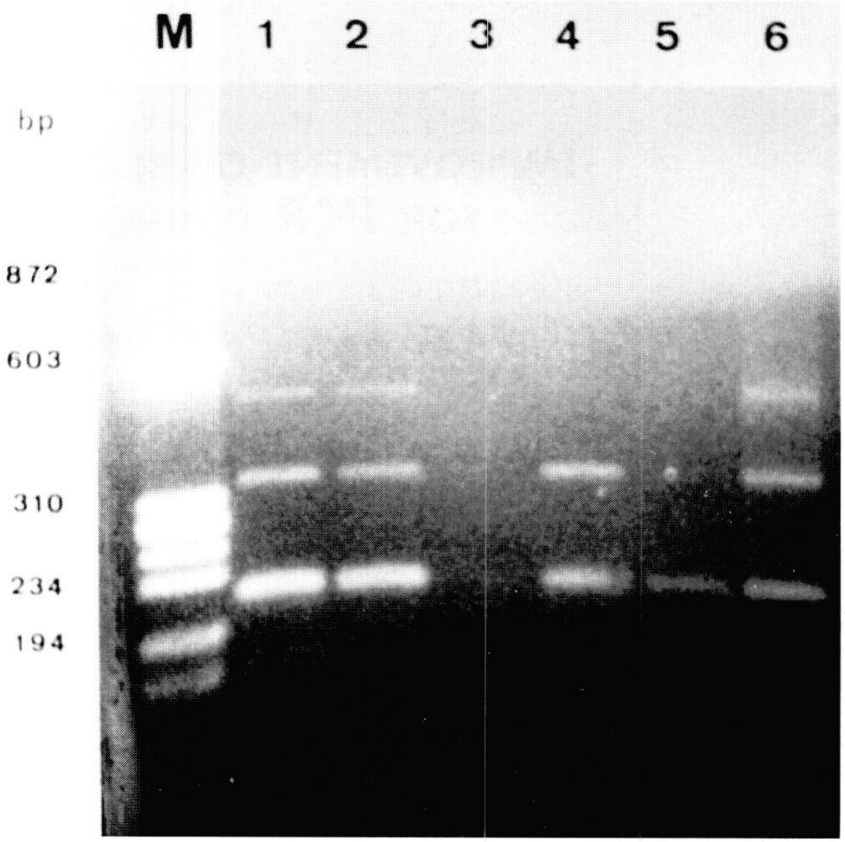

Fig. 1. - Amplification of T. brucei in blood stored at $4{ }^{\circ} \mathrm{C}$ : Marker M., $\phi x 174$ DNA/ HaeIII; 1) four trypanosomes in EDTA tube containing blood; 2) one trypanosome in EDTA tube containing blood; 3) negative control of PCR, blood without parasite; 4) four trypanosomes in dry tube containing blood; 5) one trypanosome in dry tube containing blood; 6) $10 \mathrm{pg}$ of $T$. brucei DNA.

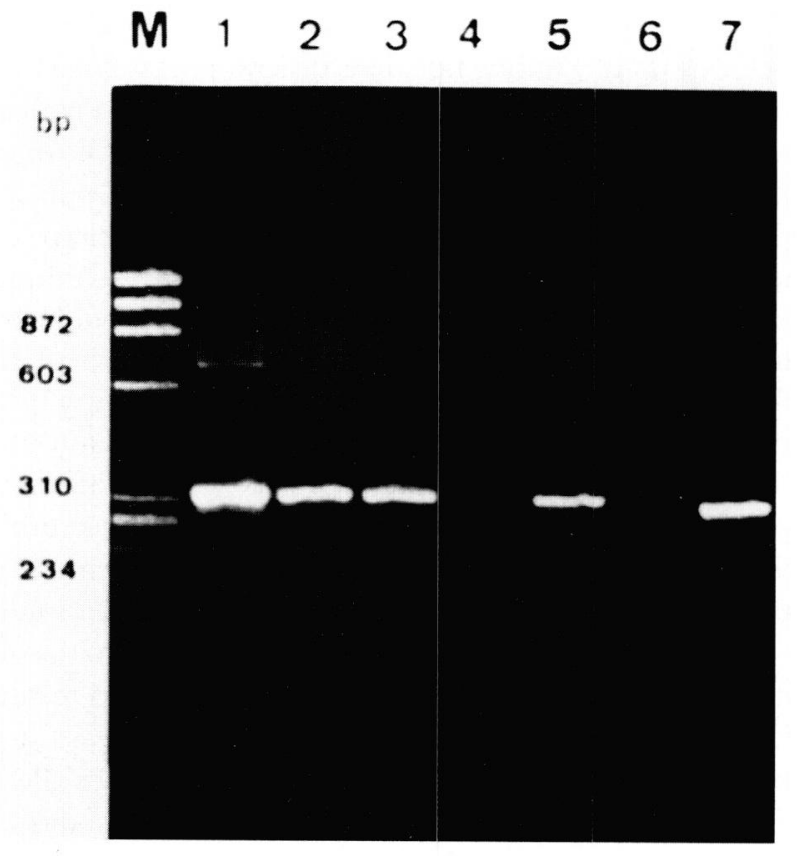

Fig. 2. - Amplification of $T$. congolense in midguts of tsetse flies. Lanes are: Marker $(M)$ as in figure $1 ; 1$ ) and 2) midguts of infected flies; 3) midgut of non infected fly with 100 trypanosomes; 5), 6) and 7), midguts of infected flies negative by microscopic observation; 6), negative control of PCR; 7), $10 \mathrm{pg}$ of $T$ congolense DNA.

lense sequences (lane 5) whereas the two others remain negative (lanes 4 and 6 ) as control flies (data not shown). 


\section{DISCUSSION}

$\mathrm{M}$ ass detection of african human trypanosomosis in done in two steps: first serological tests (Card Agglutination Test for Trypanosomosis) by blood taking (Magnus et al., 1978), and then search of parasites in seropositive patients by lymphatic gland puncture, HTC or mAEC techniques. When the presence of the parasite is confirmed, a treatment can be achieved (Penchenier and Janin, 1991) but, in many cases, parasites are not evidenced in seropositive patients, due to limitations of parasitological techniques (Penchenier et al., 1991). Since mass detection is done in distant villages, our method offers the advantage that blood samples can be kept until the end of field work, before processing in the laboratory. Although any method of blood conservation seems to work well, blood taking on anticoagulant coated tubes would be more suitable for PCR diagnosis.

Moreover, compared to blood dotting (a drop of blood is about $60 \mu \mathrm{l}$ ), the sensitivity threshold is noticeably increased since we detect one parasite in $1 \mathrm{ml}$ of blood, allowing then a more accurate diagnosis.

Epidemiological studies are also concerned, particularly those concerning the animal reservoir: the pig is a potential reservoir for human trypanosomosis (Mehlitz, 1986) and lives in close contact with human populations. Preliminary investigations in the Yemessoa region (Cameroun) strengthens the validity of our technique. PCR contaminations can be a major problem in a large epidemiological survey: these first experiments allowed us to assess our conditions of sample collection in the field, and laboratory structures and manipulations in the OCEAC center.

Direct PCR on midguts of tsetse flies underlines two important features: 1) the opportunity to detect parasitemia in negative flies by common parasitological techniques; 2) the advantage of minimizing loss of material that can occur with DNA purification. It can then provide information on the sites of contamination by identifying recently infected young flies. Even if the presence of trypanosomes does not imply that the fly becomes infective, this technique is of great interest for the detection of immature parasites.

Finally, PCR diagnosis will be very useful for veterinary surveys, particularly in detection of trypanosomes in animals with low parasitemia in the blood, for example trypanotolerant cattle and wild fauna.

\section{ACKNOWLEDGEMENTS}

WV

e thank Dominique Cuisance and JeanLouis Frézil for critical reading of the manuscript.

\section{REFERENCES}

Gibson W.C., Dukes P. \& Gashumba J.K. Species-specific DNA probes for identification of African trypanosomes in tsetse flies. Parasitology, 1988, 97, 63-73.

LANHAM S.M. \& GODFREY D.G. Isolation of salivarian trypanosomes from man and other mammals using DEAE-cellulose. Experimental Parasitology, 1970, 28, 521-534.

Magnus E., Vervoort T. \& Van Mervenne N. A card agglutination test with staired trypanosomes (CATT) for sérological diagnosis of Trypanosoma b. gambiense trypanosomiasis. Annales de la Société Belge de Médecine Tropicale, 1978, 58, 169-176.

Masiga D.K., Smith A.J., Hayes P., Bromidge T.J. \& Gibson W.C. Sensitive detection of trypanosomes in tsetse flies by DNA amplification. International Journal for Parasitology, 1992, 22, 909-918.

Mehlitz D. Le réservoir animal de la maladie du sommeil à Trypanosoma brucei gambiense. In: Etudes et Synthèses de l'IEMVT, 1986, 18, 156 p.

Moser D.R., Cook G.A., Ochs D.E., Bailey C.P., McKane M.R. \& DOnelson J.E. Detection of Trypanosoma congolense and Trypanosoma brucei subspecies by DNA amplification using the polymerase chain reaction. Parasitology, 1989, 99, 57-66.

Penchenier L., Jannin J., Moulia-Pelat J.P., Elfassi de la Baume F., Fadat G., Chanfreau B. \& Eozenou P. Le problème de l'interprétation du CATT dans le dépistage de la trypanosomiase humaine à Trypanosoma brucei gambiense. Annales de la Société Belge de Médecine Tropicale, 1991, 71, 221-228.

Penchenier L. \& Jannin J. Le traitement de la Trypanosomoses Humaine Africaine à Trypanosoma brucei gambiense (in: Some new prospects in epidemiology and fight against Human African Trypanosomiasis by E. Authie et al.). Research and Reviews in Parasitology, 1991, 51, 29-46.

Woo P.T.K. Evaluation of the hæmatocrite centrifuge and other techniques for the field diagnosis of human trypanosomiasis and filariasis. Acta tropica, 1971, 28, 298-303.

Reçu le 13 février 1996 Accepté le 26 septembre 1996 